Rolandic line, $2 \frac{1}{4}$ inches from the longitudinal fissure, thus indicating a position in the ascending parietal convolution, just behind the arm centre.

The casc is shown as one of interest in that it closely resembles an experimental lesion in its distinetly localized nature. Its situation immediately behind the Rolandic line, with no motor paralysis, empliasizes the experimental findings that the motor area proper lies only in front of this line.

\title{
RECURRENT GOITRE.
}

Dr. Ellsworth Elotot, Jr., presented a woman, 24 years old, who was admitted to the Presbyterian Hospital on May 23, Igo5. Her family and personal history was negative. The patient had always menstruated irregularly; otherwise, with the exeeption of an attack of dropsy tivelve years ago, she had enjoyed good liealth until five years before, when she first noticed the sensation of a "foreign body" in the throat, and slight enlargement of the thyroid. This swelling had gradually increased, particularly in the past year, and for the preceding month she had complained of choking sensations and diffeulty in swallowing. For five years she had suffered from bi-montlly attacks of palpitation, lasting from ten minutes to an hour. There was no headaelie; no exoplithalnıos.

An examination of the neek showed a goitre about the size of an orange, elastic and symmetrieally enlarged. The pulse ranged from 80 to 100. All operation for its removal was undertaken on May 29, 1905. After a few inhalations of ether, the patient's breathing beeame stertorous, she became cyanosed, and respiration apparently ecased and for ten minutes slie was thought to be dead. Under artificial respiration she gradually revived, and at the end of three-quarters of an hour she was practically out of danger. The operation was postponed for a week. At that time, under cocaine, enuclcation of the goitre was attempted. This was successful, so far as the separation of the goitre from the overlying and lateral museles was eoneerned, but its base proved to be adherent, and at this stage of the operation the patient became restless and complaincd of so much pain that further attempts at enucleation lad to be abandoned. The eyst was thereupon opened, and two ounees of hemorrhagic fluid evacuated and the eyst wall removed from the thyroid glancl. The wound was 
packed and allowed to heal by granulation. During this time there was a diselarge of a considerable amount of necrotic material, which upon examination proved to be portions of the thyroid gland. Healing was complete at the end of the third month, the sinus having completely closed, leaving no sign of the goitre.

The pathological report at this time was as follows.-Thyroid tissue somewhat bloody and distorted. Some tendency in places to papillation of the epithelium, which in certain areas is rather high columnar, but in others flat or cuboidlal. Colloid contents of vesicles do not stain. Comnective tissue seanty, and shows little or no inflanmatory infiltration.

The patient was re-adnitted to the hospital on October 14 , 1907, with the history that six months before she had first notieed a recurrence. There was no exophthalmos nor palpitation. The swelling had steadily increased to its original size, but had not given rise to any symuptoms of eompression. Examination showed a broad scar adherent to the lower part of an irregular, ovoid, clastic tumor, typically thyroidal. The paticnt's urine was normal.

Operation, October 16, 1907.-At this operation ether was administered, and was well borne by the patient. The left lobe of the thyroid was removed, and an examination of the specimen showed that it was made up of a number of communicating cysts around a ecentral eore, which was reddish in color. The wound healed without tronble.

The pathological report on this specimen was as follows.There is great hypertrophy of glandular tissue, which contains in places little or no colloid material; elsewhere, the alveoli are dilated and contain colloid material. The interstitial tissue in places is increased and shows hyaline degeneration. There are areas of hypertrophied glandular tissite in which 1 are several layers of epithelium superimposed. The wall of a large eyst is composed of dense fibrous tissue.

Diagnosis, eystic goitre. There were no signs of a further reenrrence up to the present time.

\section{BUFFER ACCIDENT OF KNEE.}

DR. ElLswortu El,ơr, JR., presented a man, 40 years old, who was admitted to the Presbyterian Hospital on Jantary 24, 1907. The history obtained was that on the day prior to his 
admission his left knec was caught between the buffers of two street cars, and severely erushed. Inspection showed that the lcft knee ivas greatly distencled with blood and serum, the presence of blood being indicated by blood erepitus. The entire left leg was swollen, from the thigh to the ankle. Two days after admission, the measurement of the left leg, cight inches above the patella, was 25 inches, while that of the right $\mathrm{lcg}$ at the same point was $201 / 2$ inches. Four and a lialf inches bclow the patella the left leg measured $161 / 2$ inches and the right leg two inches less. At the patella the left leg measured $19 \frac{1}{2}$ inches and the right leg 15 inches.

The left extrenity slowed evidences of extensive extravasation of blood, but pulsation could still be detected in both the anterior and posterior tibial arteries. On February 10, about two and a half weeks after his admission to the hospital, althongh there had been no laecration of the overlying skin, there were indications of an inflanmmatory process on the onter side of the leg, opposite the external condyle of the femur. A large area of necrosis developed in this region, with slight oozing of blood, and the subsequent discharge of several fragments of bone. This condition, with alteruate periods of healing and suppuration, continued for two montlis, when the original wound healed completely with the exception of a small sinus which persisted for six months. An X-ray was taken, which showed no free sequestra present. During Febriary and Marel the patient was kept in a Buck's extenision apparatus. His tempcrature, which on admission ranged from 100 to 102 , gradually fell to normal, and remained so up to the time of his diselarge from the hospital, on May 10, 1907. Ten leueocyte counts were made during his stay in the hospital, and the highest was on March 15 , when it reached I6,200; the other counts were all below 12,000 .

When Dr. Eliot next saw the paticnt, about six months after the accident, he found upon examiuation that although the affected knee was capable of some movement, the ligaments had becone stretched. To remcely this elefect, the patient liad an ordinary steel-hinge braee macle which enabled him to walk without any trouble. The patient was given the ehoice between a resection, an amputation and the brace, and chose the latter. 